\title{
Public Control in the Mechanism of Realization of the Principle of Local Authority Publicity
}

\author{
Denis S. Mikheev \\ Igor G. Dudko \\ Tatiana N. Mikheeva \\ Mari State University, Yoshkar-Ola, Russia \\ Email:mikheev_ds@mail.ru
}

Doi:10.5901/mjss.2015.v6n3s7p41

\begin{abstract}
The article is devoted to the role of public control when exercising local authority publicity. Scientists point out that in legal regulation of local government modern states lay emphasis on publicity as the basic fundamental principle and consider it a tool that connects local authorities with citizens of municipal entities (Mikheev, 2014). The aim of the work is the investigation of the mechanism of the principle of publicity at the municipal level. The analysis of the elements of the principle shows that public control is one of the key directions in its realization. However, this social institution is not sufficiently studied. The issue of the federal legal act hasn't improved the situation. According to V.V.Grib, law is not capable to ensure the full legal regulation of the relations concerning the exercise of public control (Grib, 2014). As a result of assessment of the modern state of public control, the authors have elicited the specific character of its exercise at the municipal level. Legal algorithms were proposed. They can make the mechanism of public control work. The number of proposals concerning the improvement of federal legislation and normative lawmaking at the level of subordinate entities of the Federation was made. In this connection, this investigation is notable for its scientific novelty and as it has practical implication for exercising public control in local societies. Authors' conclusions can be used in scientific work for studying problems of local authority publicity, public control, interaction between citizens and local authorities.
\end{abstract}

Keywords: local government, principles, publicity, public control, realization

\section{Introduction}

The most important condition of the effective development of local government as the independent level of public authority is its interaction with citizens and civil society institutions. According to A. A. Yaroshenko, this accounts for the aim of local authority to make people's life and solution of local problems most comfortable (Yaroshenko, 2002). At the same time, problems of local government can't be demonstrably solved without citizen participation.

Scientists refer to such practice in some foreign states where the state develops support of citizens' initiatives in municipal sphere, authority's consultations with a territorial collective which precede decision-making concerning local life (Mikheev D.S., Mikheeva T.N., Mokoseeva M.A., 2015).

It stands to reason that in his annual Address to the Federal Assembly on December 4, 2014, the President of the Russian Federation mentioned the growing civic activeness: "They not only set questions to the authority, but also participate in their solution, understanding that a lot of things depend on their efforts" (Russian President's Address, 2014).

In previous years the head of state also paid attention to the necessity of approaching of local authority to the public so that any citizen could reach it with his hand (Russian President's Address, 2013). Legal nature of local government emanates from the fact that this is the level of public authority that is mostly close to its source - the public (Mikheeva, 2012).

At the same time openness and transparency of activity of local government for the public, citizens' access to the information about such activity are necessary for the citizens' involvement into the processes of local life. There are also other factors of approaching of local bodies to the citizens such as the possibility of public control of the work of local government by the public and, in its turn, local government must find out and take into account the public's opinion when making decisions. All the enumerated characteristics are includes into the legal notion of the principle of local authority 
publicity which realization became one of the topical problems in municipal entities in modern conditions. There are also certain gaps in the theoretical insights into this principle.

However, out of all the elements of the principle the direction of public control causes the most research interest. It remains scarcely investigated in science, didn't get the wide legal regulation. A few scientists refer to this problem, though the idea of public control at the local level itself isn't new (Mikheev, 2013). In 1928 the classic of Russian municipalism, L.A. Velikhov told about it indirectly, pointing out that freedom of municipal authorities must be limited with legitimate electorate's interference (Velikhov, 1928).

Recently studies justifying the necessity of public control, its treatment as the independent form of control at the local level begin to appear (Yaichnikova, 2010).

The certain legal clarity was brought into solution of the problem under study with the federal law (the Federal Law "About the bases of public control in the Russian Federation", 2014). However, it didn't manage to exercise the full legal regulation of this problem.

Justification of the place and the role of public control in the mechanism of realization of the publicity principle is in need of additional expanded investigation.

\section{Methods}

Investigation methodology covers general scientific methods, for example, the dialectical method. Ways of scientific knowledge, specific for law, were also applied.

The systematic approach was used when analyzing the principle of local authority publicity and discovering its elements. Among them public control of work of local government came to the front.

The principle of scientific objectivity let carry out the thorough and objective analysis of factual material, all the facts, influencing the interaction between civic institutions and local government in the part of public control. Reference to the formal lawful method let analyze normative legal acts, discover in them the peculiarities of entrenchment of the publicity principle, the possibility of public control. The comparative legal method was applied when referring to the experience of legal regulation and realization of the principle of local authority publicity in foreign countries. It let discover the mechanism and peculiarities, the tendency to the development of publicity and one of its elements - public control.

In the research other investigation methods, which let study and cover the topic, were also applied.

\section{Results and Discussion}

Local government is the closest to citizens level of public authority. Citizens of municipal entities take part in the exercise of local self-government directly or through elected and other bodies of local authority. Because of this, municipal bodies are in the constant contact with people when conducting their activities. Increase of democracy and further development of local government are impossible without legislating of effective and working forms of interaction between local government and public associations, working at the local level and including the most active and responsible citizens of the municipal entity (Hyden, 1997).

Interest of citizens and civic institutions in solution of local problems is the factor that provides their cooperation with local authority. Certainly, it is impossible to force civic institutions into the active volition decisions, but it is necessary to work out clear legal algorithms which let citizens cooperate with local government and to be heard with it (Mikheev, 2012). Another important condition of such cooperation is publicity and openness of work of local authority. The principle of publicity is dominant in relations of authority and people in local communities.

It comprises such important elements as the approach of people to the information about the work of municipal bodies, revelation and account of the public opinion when making decisions by local government, citizens' possibility to influence the decision-making by local government. No less important point is people's possibility to control the work of bodies that were created in the local community with citizens' participation. Nowadays public control is turning into the priority direction in the mechanism of realization of the publicity principle. For a long time it remained little investigated from theoretical points and was without corresponding legal regulation. In this state public control in municipal practice was a very rare phenomenon.

A year ago certainty was brought to this question with the Federal Law "About the bases of public control in the Russian Federation". However, it regulates legal relations of public control of work of both state and local authority. We are of the opinion that public control in the sphere of local authority has its own peculiarities and must be considered in terms of exercising publicity.

Here the question about subjects and objects of public control is reasonable. They will differ from the federal level 
with their closeness to the territory of local government, spheres under test, limited by local questions. In Article 9 of the Law, mentioned above, it is pointed out that subjects of public control are public chambers of all levels: federal, regional and public chambers (councils) of municipal entities. For these purposes, it is also accepted to form public monitoring committees, public inspections, public control groups and other organized structures of public control.

Speaking about subjects of public control at the local level, it is necessary to pay attention to one important circumstance. Public chambers are formed in far from all the municipalities. In some of them public councils are established. They are also authorized to exercise public control. However, they aren't, as a rule, formed by local authorities as some supervising-advisory public structures and aren't aimed at exercising functions of public control; they are dependant from local authorities.

In this connection, it is necessary to consider legal peculiarities of establishing public chambers (councils) in municipal entities. Such bodies must be formed and spread everywhere, because their absence causes obstacles for progressive development of public control.

It should be pointed out that the federal law is limited only with legal bases in this direction, leaving a lot of aspects without regulation. Now it is high time to bring legal certainty and specification to the subordinate entities of the Federation. In regional laws about the public control they have the right to offer forms of establishing named bodies, the procedure of exercising functions of public control.

We consider that it is necessary to limit the establishment of public chambers only with the level of urban and municipal districts. It isn't reasonable to form them in small settlements. It is known that in rural settlements with the number of people, who have the right to vote, up to 100 people all the most important local questions are set up by citizens straight at the gathering.

The institution of public chambers at the municipal level is comparatively new. Little practice points to the fact that it is mainly developed in urban districts. However, in some regions of Russia, for example, in Voronezh Region, they are established in all the urban and municipal districts. The experience of their establishment shows that municipal public chambers are formed, as mentioned above, by local authorities themselves. They are formed with the decision of the head of the municipal entity or the representative body of local government. Such establishing order can't be recognized from publicity points. It must be more democratic and provide people, public organizations in the municipal and urban districts with rich opportunities for nomination of candidates in the local public chamber. The right to nominate candidates as members of the municipal public chamber must be given to registered public associations, noncommercial organizations which operate in a municipal entity. Apart from that, local authorities must be excluded from the process of formation of specified public structures. This power must be devolved on regional public chambers.

Public associations are considered as the basic institution of civil society. In V.V. Grib's opinion, they hold the right to represent functional interests and express the will of citizens. Their main duty is advocacy (Grib, 2010). It stands to reason that in social theories of the $20^{\text {th }}$ century public organizations are admitted as the fundamental principle for the development of basics of self-government and democracy, the achievement of progress in all the spheres of social life (Habermas, 1989). Public, associations formed in municipal entities, unite active citizens. They show interest and concern with various local questions, are well-organized associations of citizens and are capable to exercise public control. Voluntariness that is in the basis of establishment of public associations and their activities, which are connected with citizens' interests, speak for local public associations as the most qualified subject of public control. We suggest that a lot of socially oriented noncommercial organizations that confidently make a name for themselves at the local level can be qualified enough to conduct the public interest test or the public examination.

The solution of the problem is possible if the Federal Law is amended or the subjects of the Russian Federation pass their own legislative acts. From the point of publicity, the outspread of subjects of public control lets make the publiccontrol activity more open, public, forms additional legislative mechanisms for the organization of a new social institution. Apart from that, the involvement of additional local resources into the sphere of public control will expand citizens' approach to the information about many directions of the municipal activities, will provide people with additional possibilities to influence the process of making decisions by local authorities.

The analysis of the Federal Law "About the bases of public control in the Russian Federation" shows that the question about objects of public control remained unsettled, there is no special prescription devoted to this important aspect. The fact is that in Article 9 it is indirectly indicated that "the activities of local authorities, municipal organizations that exercise definite public power" are subject to public control. However, the term "public power" remains not clear for the ordinary representative of local community. In this part, it becomes clear that the activities that is subject to public control must be specified. It should be pointed out that not all the duties of local authorities must be controlled by people. For example, S.V. Pylin considers the activities that are connected with exercising local government, observance and protection of human and civil rights and liberties, as the object of public control (Pylin, 2006). Y.S. Yaichnikova supports 
his opinion and adds the sphere of public control with another direction - control of legitimacy of decisions and municipal legal acts (Yaichnikova, 2011).

Thus, we may conclude that public control must be directed at the spheres of activities of municipal bodies that affect the interests of people, public associations, civil rights and liberties, safety, stable development of a municipal entity. Public control in the municipal sphere as it is stated in the principle of local authority publicity is aimed at testing and examination of the activities of municipal bodies on the territory of the municipal entity whether they correspond to the public interests. The category "public interests" must be the basis of the object of public control and be legitimated.

\section{Conclusion}

Concluding the brief investigation, it is necessary to sum some results. Local authorities are to settle the questions at the local level, in other words, citizens' life necessities in the community. This process will be successful when citizens themselves begin to display interest and activity. Publicity as the fundamental principle of local government encourages this.

Public control holds key positions in the mechanism of realization of the principle of local authority publicity. However, a lot of questions concerning its organization remain unsettled nowadays. The analysis of the Federal Law "About the bases of public control in the Russian Federation", conducted by authors, showed that it needs to be completed. Part of unsettled questions must be regulated by corresponding laws of the subjects of the Russian federation. Legislative proposals are as follows:

- to add the checklist of subjects of public control in local communities, having provided an opportunity to participate in it for local public associations, noncommercial organizations apart from public chambers and public councils of municipal entities;

- to exclude the possibility of establishment of public chambers and public councils by local authorities themselves, having given this right to public chambers of the subjects of the Russian federation;

- $\quad$ to define by law the object of public control, having accepted as its basis the activities of municipal bodies concerning solution to questions at the local level. Public control must review them for compliance with public interests.

The specification of legislative rules will considerably simplify the process of enforcement, contribute to the development of the institution of public control.

\section{Acknowledgements}

The authors are grateful to the Russian Humanitarian Science Foundation (URL: http://www.rfh.ru/index.php/ru/) for the opportunity to conduct this investigation within the grant project "Innovative approaches and mechanisms of realization of publicity in the activities of local authorities" (the contest to support young scientists of 2015, project number № 15-3301364).

\section{References}

Grib, V.V. (2010). Interaction between state authorities and institutions of civil society. M.: Publishing house Yurist. P.109-110 (378).

Grib, V.V. (2014). By-article scientific practical commentary of the Federal Law No. 212-FZ of July 21, 2014 "About the bases of public control in the Russian Federation". Moscow. P.7.

Habermas, J. (1989). The Structural Transformation of the Public Sphere. Camburg.

Hyden,G. (1997). Civic society, social capital, and development: Dissection of complex discourse. Studies in Comparative International Development, 32 (1), 3-30. http//dx.doi.org/:: 10.1007/BF02696304.

Mikheev, D.S. (2014). Legal Analysis of the European Charter of the Local Se Government in The Light of the Principle of Publicity. Life Science Journal, 11 (6), 619-622.

Mikheev,D.S. (2012). Interaction between citizens and municipal bodies as the mechanism of exercising the principle of local authority publicity. Russian justice.№ 7. P.17-19,

Mikheev, D.S. (2013). The principle of local authority publicity: monograph. Yoshkar-Ola. P. 307 (375).

Mikheev, D.S., Mikheeva T.N., Mokoseeva M.A. (2015). On the experience of legal regulation of the principle of local authorities in German law. Review of European Studies. Volume 7, No 8, 23-27, http//dx.doi.org/: 10.5539/res.v7n8p23

Mikheeva, T.N. (2012). Peculiarities of the modern institution of local government. Eurasian law journal. №2 (45). P.58-59.

Presidential Address to the Federal Assembly on 12 December 2013 (2013). Rossiyskaya Gazeta, 13 December.

Presidential Address to the Federal Assembly on 4 December 2014 (2014). Rossiyskaya Gazeta, 5 December.

Pylin, S.V. (2006). Municipal control: problems and ways of enforcement. Consitutional and municipal law. №11. P.33. 
The Federal Law No. 212-FZ of July 21, 2014 "About the bases of public control in the Russian Federation". (2014). Legislation Bulletin of the Russian Federation, №30 (part 1), P. 4213.

Velikhov, L.A. (1928). The foundations of municipal economics. In the book: Govorenkova T.N. Read Velikhov together. M., 1999. P. 119.

Yaichnikova, Y.S. (2011). Problems of control of the activities of local authorities. Monograph. Yoshkar-Ola. P. 10 (223).

Yaichnikova, Y.S.(2010). Exercising public control of local authorities. About the interaction between social institutions and representative bodies of local government. Yoshkar-Ola. P.64.

Yakhina, O., Vavilov, N., Mikheev, D. (2015) Availability of Municipal Services as a Means of Communication of Municipal Authorities and Citizens. Review of European Studies, Volume 7, No 8, 227-232, http//dx.doi.org/: 10.5539/res.v7n8p227

Yaroshenko, A.A. (2002). Local government in the system of state power. State power and local government. 2004. № 7.P.37. 
